\title{
Deposition of nitrogen and phosphorus on the Baltic Sea: seasonal patterns and nitrogen isotope composition
}

\author{
C. Rolff ${ }^{1}$, R. Elmgren ${ }^{1}$, and M. Voss ${ }^{2}$ \\ ${ }^{1}$ Department of Systems Ecology, Stockholm University, 10691 Stockholm, Sweden \\ ${ }^{2}$ Leibniz Institute for Baltic Sea Research, Seestr. 15, 18119 Rostock, Germany
}

Received: 1 July 2008 - Published in Biogeosciences Discuss.: 6 August 2008

Revised: 23 October 2008 - Accepted: 27 October 2008 - Published: 10 December 2008

\begin{abstract}
Atmospheric deposition of nitrogen and phosphorus on the central Baltic Sea (Baltic Proper) was estimated monthly at two coastal stations and two isolated islands in 2001 and 2002. Yearly nitrogen deposition ranged between 387 and $727 \mathrm{mg} \mathrm{N} \mathrm{m}^{-2} \mathrm{yr}^{-1}$ (average $~ 617$ ) and was composed of $\sim 10 \%$ organic $\mathrm{N}$ and approximately equal amounts of ammonium and nitrate. Winter nitrate peaks at the isolated islands possibly indicated ship emissions. Load weighted $\delta^{15} \mathrm{~N}$ of deposited $\mathrm{N}$ was $3.7 \%$ and $0.35 \%$ at the coastal stations and the isolated islands respectively. Winter $\delta^{15} \mathrm{~N}$ was $\sim 3 \%$ o lighter than in summer, reflecting winter dominance of nitrate. The light isotopic composition of deposited nitrogen may cause overestimates of nitrogen fixation in basinwide isotopic budgeting, whereas relatively heavy deposition of ammonium during summer instead may cause underestimates of fixation in budgets of the upper mixed layer. $\delta^{15} \mathrm{~N}$ in atmospherically deposited nitrate and ammonium was estimated by regression to -7.9 and $13.5 \%$ respectively. Phosphorus deposition showed no clear seasonal pattern and was considerably lower at the isolated islands. Organic P constituted $20-40 \%$ of annual $\mathrm{P}$ deposition. $\mathrm{P}$ deposition is unlikely to be a major source for cyanobacterial blooms but may potentially prolong an ongoing bloom.
\end{abstract}

\section{Introduction}

\subsection{Study area}

The Baltic Sea is a low-diversity, non-tidal, brackish, fjordlike, estuarine water body (Kullenberg, 1981) consisting of series of large basins separated by sills. The surface salinity ranges from $\sim 2$ in the northernmost part to $\sim 10$ at the

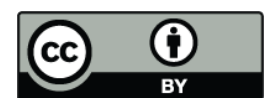

Correspondence to: $\mathrm{M}$. Voss (maren.voss@io-warnemuende.de)
Danish sounds which connect the Baltic Sea to the North Atlantic. The deep-water salinity ranges from $\sim 3$ to $\sim 20$ and is renewed by intermittent major inflows of water with higher salinity. The central part of the Baltic Sea is called the Baltic Proper and has a stable halocline at $60-70 \mathrm{~m}$, which separates the surface waters from the more saline deep water. In the periods between major inflows, anoxia develops in the deeper areas and periodically the entire water-body below the halocline becomes anoxic. Eutrophication has been a major cause of concern for the development of anoxia (Elmgren, 2001) and by adopting the Helsinki Convention in 1992 the countries in the Baltic region agreed to prevent and reduce the pollution of the Baltic Sea. The Helsinki Commission (HELCOM) coordinates monitoring and collects load data for polluting substances in the Baltic Sea and publishes them in Pollution Load Compilations the fourth of which (PLC4) was published in 2004 .

\subsection{Atmospheric nitrogen deposition in the Baltic Sea}

Anthropogenic processes changed the global nutrient cycles dramatically in the last century (Gruber and Galloway, 2008). Combustion of fossil fuels and intensified agricultural practices now emit huge quantities of nitrogen to the atmosphere, making atmospheric deposition a major nitrogen source for coastal and open marine systems (Duce et al., 2008; Galloway et al., 2004; Paerl, 1995, 1997). Recent estimates for the Baltic Sea have atmospheric deposition contributing a quarter to a third of the total estimated external annual load of $\sim 1$ million tons of nitrogen (Hertel et al., 2003; HELCOM 2004). Reduction of airborne emissions is therefore a top priority for most nations but detection of the origin of polluting substances is complex. The trajectories of air masses change continuously and atmospheric processes cause the nutrient species deposited to differ from those originally emitted. To make emission reductions cost efficient it is important to identify the sources of polluting substances.

Published by Copernicus Publications on behalf of the European Geosciences Union. 
Stable isotope methods are increasingly used to trace the origin and fate of substances in biogeochemical cycles, and the isotopic composition of nitrogen in precipitation and aerosols has recently been used as a tool to identify the sources of atmospheric compounds (Russell et al., 1998; Yeatman et al., 2001a, b). Reductions of emissions to the atmosphere are likely to change not only the amounts and speciation, but also the isotopic signature of atmospheric combined nitrogen. If the isotopic composition in the deposited nitrogen changes in accordance with those in the emissions it is likely that the correct abatement measures have been taken, if not the studied emission may not be a main contributor to deposition in the studied area. By knowing the isotopic composition of the sources in a biogeochemical process it is in many cases possible to quantify the relative contribution from different sources to an end product. The isotopic signatures of materials in natural systems do however generally not differ drastically, making isotopic budgets sensitive to errors in the estimated isotopic composition of the components. In isotopic budget calculations for Baltic Sea nitrogen, the atmospheric deposition is a major component but its average isotopic composition is unknown, thereby causing uncertainty. The main aim of this study was therefore to characterize seasonal changes in the isotopic composition of atmospherically deposited nitrogen in the Baltic Proper, and to calculate an annual load-weighted average of isotopic composition as a baseline information for future studies in the region.

\subsection{Atmospheric phosphorus deposition}

The most interesting aspect of atmospheric P-deposition is its potential effect on the summer blooms of filamentous nitrogen-fixing cyanobacteria of the genera Nodularia and Aphanizomenon which are a considerable internal source of nitrogen for the Baltic Sea. This nitrogen fixation has been estimated to $180-430$ ktons nitrogen per year and is assumed to be limited by phosphorus availability (Larsson et al., 2001). The isotopically light fixed nitrogen rapidly appears in all size fractions of the plankton community (Rolff and Elmgren, 2001), suggesting a strong impact on the pelagic production. This fixed nitrogen has been estimated to potentially sustain $30-90 \%$ of the pelagic net community production in the Baltic Proper during June-August (Larsson et al., 2001). As the blooms develop the cellular molar carbon to phosphorus $(\mathrm{C}: \mathrm{P})$ ratio of the dominant cyanobacterium, Aphanizomenon, increases 13-fold to $\sim 420$, from well below a standard Redfield ratio to four times Redfield. The highest C:P ratios are associated with the decline of the bloom and suggest phosphorus limitation of the cyanobacterial production once the internal and external phosphorus supply is exhausted (Larsson et al., 2001). Since the cyanobacteria appear to be able to grow at very low phosphorus levels the atmospheric deposition of phosphate, albeit low, may be of importance in sustaining cyanobacterial blooms.
Quantitatively the atmospheric load of phosphorus on marine areas is generally considered to be small in relation to other loads (Krom et al., 2004). Recent estimates however indicate that atmospheric phosphate deposition can sustain up to $38 \%$ of new production during summer and autumn in the eastern Mediterranean (Markaki et al., 2003). To our knowledge there is no recent estimate of annual phosphorus deposition in the Baltic Sea and there are also few from other marine areas (e.g. Ahn, 1998; Ahn and James, 1999; Herut et al., 1999; Morales et al., 2001; Pollman et al., 2002; Markaki et al., 2003; Koelliker et al., 2004). We also studied the organic component of atmospheric deposition for both nitrogen and phosphorus, since the organic portion has been suggested to be $20-30 \%$ of total nitrogen deposition and to be potentially important in coastal eutrophication (Peierls and Paerl, 1997; Scudlark et al., 1998). In this study the deposition of total nitrogen, nitrate, ammonium, total phosphorus and phosphate was measured monthly at four stations during 15 months. The isotopic composition of total nitrogen was analysed and the seasonal patterns were analysed in relation to loads and the proportions of nitrogen species in the samples.

\section{Methods}

\subsection{Sampling}

Atmospheric deposition (rainwater and dry deposition) was collected at monthly intervals from May 2001 to $\mathrm{Au}$ gust 2002 at four land-based stations in the western Baltic Proper (Fig. 1). The southernmost station, Sännen (SA), was located $\sim 16 \mathrm{~km}$ inland at a small lake and was included to give information on deposition in the southern Baltic Proper. The other three stations, Majstre (MJ), Gotska Sandön (GS) and Svenska Högarna (SH) were all on islands and within a few hundred meters from the sea. Majstre is on the southern tip of the large island of Gotland, whereas Gotska Sandön and Svenska Högarna are isolated islands in the open sea. The sampling at SA and MJ was started in May 2001 and at GS and SH in July 2001.

The collectors consisted of a plastic funnel (diameter: $20.3 \mathrm{~cm}$ ) leading water into an 81 polyethylene plastic bag, tightly fitted to the spout of the funnel. To prevent contamination by insects and particles, a smaller funnel with a $500 \mu \mathrm{m}$ nylon mesh was fitted inside the larger funnel, with a water-tight seal. Each plastic bag was protected inside a 5-litre polyethylene container, and the whole construction shielded from light by a PVC shell, to prevent photosynthetic production, and mounted on a wooden pole, $1.5-2 \mathrm{~m}$ above ground in an open area. The opening of the collector was fitted with a bird ring or a fringe of sharp spikes to deter birds from landing. The Swedish national long-term monitoring program for rain chemistry uses this type of collector and the two southernmost stations are also part of that program 


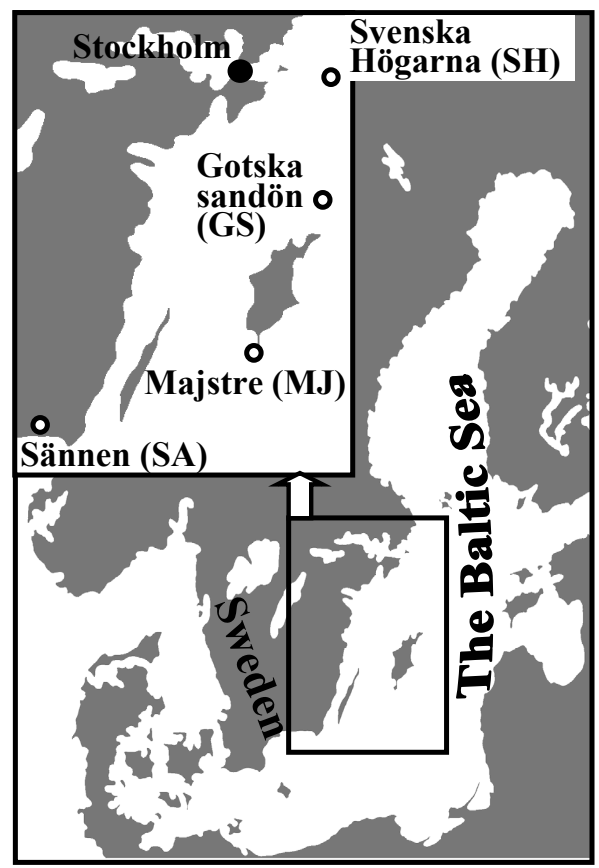

Fig. 1. Map of sampling sites.

(Kindbom et al., 2001). Any effects on the concentrations of $\mathrm{NH}_{4}^{+}$and $\mathrm{NO}_{3}^{-}$and the $\mathrm{NH}_{4}^{+}$to $\mathrm{NO}_{3}^{-}$ratio during collection and storage should be small. At each monthly sampling new polyethylene bags and nylon meshes were fitted on machinewashed replacement funnels. The volume of collected precipitation was measured, and a sample sent to the lab in a cooling container. Two collectors were used at each station to safeguard against contamination.

\subsection{Analyses}

In the laboratory, the water samples were inspected by eye and rejected if strongly coloured, or if the nylon mesh had significant amounts of particles. Conductivity was measured to detect possible salt contamination from sea spray, but elevated conductivity $\left(>9 \mathrm{mS} \mathrm{m}^{-1}\right)$ was never found. The sample was then filtered through a $40 \mu \mathrm{m}$ nylon pre-filter and then by under pressure filtration onto $25 \mathrm{~mm}$ Whatman GF/F glass-fibre filters (precombusted $4 \mathrm{~h}$ at $400^{\circ} \mathrm{C}$ ) fitted in glass filter holders. The filtrate was analysed for nitrate + nitrite, ammonium and phosphate by segmented flow analysis (SFA) and for total nitrogen and phosphorus by persulphate digestion (Koroleff, 1983). Organic nitrogen and phosphorus was calculated as the difference between total nitrogen or phosphorus and the corresponding summed inorganic forms. In a few instances the difference was minutely negative, which was interpreted as absence of organic fraction. Monthly loads were calculated as the monthly product of the concentration of each nutrient species and the precipitation.
For each sample, a subsample containing $\sim 10 \mu$ moles of nitrogen, was reduced to $\sim 5 \mathrm{ml}$ at $50^{\circ} \mathrm{C}$ in a vacuum rotavapor (Laborota 4000), and freeze dried onto a $25 \mathrm{~mm}$ Whatman GF/F glass-fibre filter (precombusted $4 \mathrm{~h}$ at $400^{\circ} \mathrm{C}$ ) for isotopic analysis. The samples were not acidified since they were slightly acidic after reduction ( $\mathrm{pH} \mathrm{5-6).} \mathrm{The} \mathrm{filters}$ were combusted in a flash EA 1112 elemental analyser at $1080^{\circ} \mathrm{C}$ and the gas carried in a He stream to a Delta plus isotope ratio mass spectrometer. Every 5th sample was a lab internal standard substance (Peptone from Merck Chemicals) that gave an overall precision of $\pm 0.2 \%$ o. The isotopic composition $\left(\delta^{15} \mathrm{~N}\right)$ is reported in per mil deviation from the standard, atmospheric nitrogen gas (which by definition has a $\delta^{15} \mathrm{~N}$ value of $0 \%$ ), according to the standard equation: $\delta^{15} \mathrm{~N}(\% o)=\left(R_{\text {sample }} / R_{\text {standard }}-1\right) \times 1000$, where $R$ is the ratio ${ }^{15} \mathrm{~N} /{ }^{14} \mathrm{~N}$ in the sample and the standard. All sample treatments and analyses were done in laboratories with an accredited protocol. The terms "lighter" and "heavier" will be used in the meaning "lower ${ }^{15} \mathrm{~N}$ content" and "higher ${ }^{15} \mathrm{~N}$ content" respectively. The isotopic composition of total nitrogen derived from the analysed filters will be denoted $\delta^{15} \mathrm{~N}_{\text {tot }}$. End member calculations of nitrate and ammonium concentrations in the deposition based on the stable isotope ratios should be considered with some caution since the estimates can only be approximations of long term averages. All statistical analyses were performed with Statistica 6.1 (StatSoft, Inc.).

\section{Results}

3.1 Precipitation and volume weighted average nutrient concentrations

The two study years differed considerably in the seasonal distribution of the precipitation (Fig. 2). In 2001 the early summer was relatively dry but late summer and autumn were wet, whereas in 2002 the summer started wet but ended with an unusually warm and dry August. It was therefore not appropriate to calculate combined seasonal averages for the two summers. Data are missing from MJ in July 2001 and April 2002 because of technical problems and from MJ and SH in August 2002 because of drought. In May 2002 the sample from SH was used up for the analysis of $\delta^{15} \mathrm{~N}$. July 2001 to June 2002 was therefore the most complete period, and was used to calculate annual estimates. Missing concentration data were interpolated from the previous and next months at the same station and missing precipitation data were obtained from adjacent meteorological monitoring stations (source Swedish Meteorological and Hydrological Institute).

Monthly precipitation (Fig. 2) ranged from zero at SH in August 2002 (and $1.9 \mathrm{~mm}$ at GS the same month) to $152 \mathrm{~mm}$ at SA in September 2001, the latter being an exceptionally high value for Sweden. The estimated July 2001 to June 2002 
Table 1. Monthly precipitation, annual loads of nitrogen and phosphorus by species for the period July 2001 to June 2002 , load weighted annual averages (LWAA) of $\delta^{15} \mathrm{~N}_{\text {tot }}$ and N/P-ratio (by weight) at the fours stations SA, MJ, GS and SH. Percent of total load in brackets.

\begin{tabular}{|c|c|c|c|c|c|c|c|c|c|c|}
\hline \multirow[t]{2}{*}{ Station } & \multirow{2}{*}{$\begin{array}{l}\text { Precip. } \\
\text { mm }\end{array}$} & \multicolumn{2}{|c|}{ Nitrogen annual loads } & \multirow[b]{2}{*}{$\begin{array}{c}\text { Organic-N } \\
\mathrm{mg} \mathrm{m}^{-2} \mathrm{yr}^{-1}\end{array}$} & \multirow[b]{2}{*}{$\begin{array}{c}\text { Total } \mathrm{N} \\
\mathrm{mg} \mathrm{m}^{-2} \mathrm{yr}^{-1}\end{array}$} & \multirow{2}{*}{$\begin{array}{l}\text { LWAA } \\
\delta^{15} \mathrm{~N}_{\text {tot }}\end{array}$} & \multicolumn{3}{|c|}{ Phosphorus annual loads } & \multirow[b]{2}{*}{$\begin{array}{l}\mathrm{N} / \mathrm{P} \text { ratio } \\
\text { (by mass) }\end{array}$} \\
\hline & & $\begin{array}{c}\mathrm{NH}_{4}-\mathrm{N} \\
\mathrm{mg} \mathrm{m}^{-2} \mathrm{yr}^{-1}\end{array}$ & $\begin{array}{c}\mathrm{NO}_{3}-\mathrm{N} \\
\mathrm{mg} \mathrm{m}^{-2} \mathrm{yr}^{-1}\end{array}$ & & & & $\begin{array}{c}\mathrm{PO}_{4}-\mathrm{P} \\
\mathrm{mg} \mathrm{m}^{-2} \mathrm{yr}^{-1}\end{array}$ & $\begin{array}{c}\text { Organic } \mathrm{P} \\
\mathrm{mg} \mathrm{m}^{-2} \mathrm{yr}^{-1}\end{array}$ & $\begin{array}{c}\text { Total P } \\
\mathrm{mg} \mathrm{m}^{-2} \mathrm{yr}^{-1}\end{array}$ & \\
\hline MJ & 657 & $336(48 \%)$ & $296(43 \%)$ & $63(9 \%)$ & 695 & 3.8 & $5.9(80 \%)$ & $1.5(20 \%)$ & 7.4 & 94 \\
\hline GS & 533 & $155(40 \%)$ & $200(52 \%)$ & $32(8 \%)$ & 387 & 0.7 & $2.0(69 \%)$ & $0.88(31 \%)$ & 2.8 & 136 \\
\hline $\mathrm{SH}$ & 618 & $220(33 \%)$ & $367(56 \%)$ & $72(11 \%)$ & 659 & 0.0 & $2.0(60 \%)$ & $1.3(40 \%)$ & 3.3 & 200 \\
\hline Average & 643 & $265(43 \%)$ & $291(47 \%)$ & $61(10 \%)$ & 617 & & & & & \\
\hline
\end{tabular}

Table 2. Volume weighted average concentrations (VWAC) of nitrogen and phosphorus by species and stations for the whole sampling period. Percent of total concentrations in brackets.

\begin{tabular}{|c|c|c|c|c|c|c|c|}
\hline \multirow[b]{2}{*}{ Station } & \multicolumn{7}{|c|}{ Volume weighted concentrations } \\
\hline & $\begin{array}{c}\mathrm{NH}_{4}-\mathrm{N} \\
\mu \mathrm{g} \mathrm{l}^{-1}\end{array}$ & $\begin{array}{c}\mathrm{NO}_{3}-\mathrm{N} \\
\mu \mathrm{g} 1^{-1}\end{array}$ & $\begin{array}{r}\text { Organic-N } \\
\mu \mathrm{g} l^{-1}\end{array}$ & $\begin{array}{r}\text { Total N } \\
\mu \mathrm{g} 1^{-1}\end{array}$ & $\begin{array}{l}\mathrm{PO}_{4}-\mathrm{P} \\
\mu \mathrm{gl}^{-1}\end{array}$ & $\begin{array}{c}\text { Organic-P } \\
\mu \mathrm{g} \mathrm{l}^{-1}\end{array}$ & $\begin{array}{l}\text { Total P } \\
\mu \mathrm{g} \mathrm{1^{-1 }}\end{array}$ \\
\hline SA & $480(49 \%)$ & $383(39 \%)$ & $108(11 \%)$ & 971 & $19.3(81 \%)$ & $4.4(19 \%)$ & 23.7 \\
\hline MJ & $476(47 \%)$ & $446(44 \%)$ & $91(9 \%)$ & 1014 & $14.5(88 \%)$ & $2.0(12 \%)$ & 16.3 \\
\hline GS & $301(43 \%)$ & $353(50 \%)$ & $53(7 \%)$ & 708 & $4.0(73 \%)$ & $1.5(27 \%)$ & 5.5 \\
\hline SH & $355(35 \%)$ & $561(55 \%)$ & $111(11 \%)$ & 1027 & $3.2(63 \%)$ & $2.0(39 \%)$ & 5.1 \\
\hline Average & $403(43 \%)$ & $436(47 \%)$ & $91(10 \%)$ & 930 & & & \\
\hline
\end{tabular}

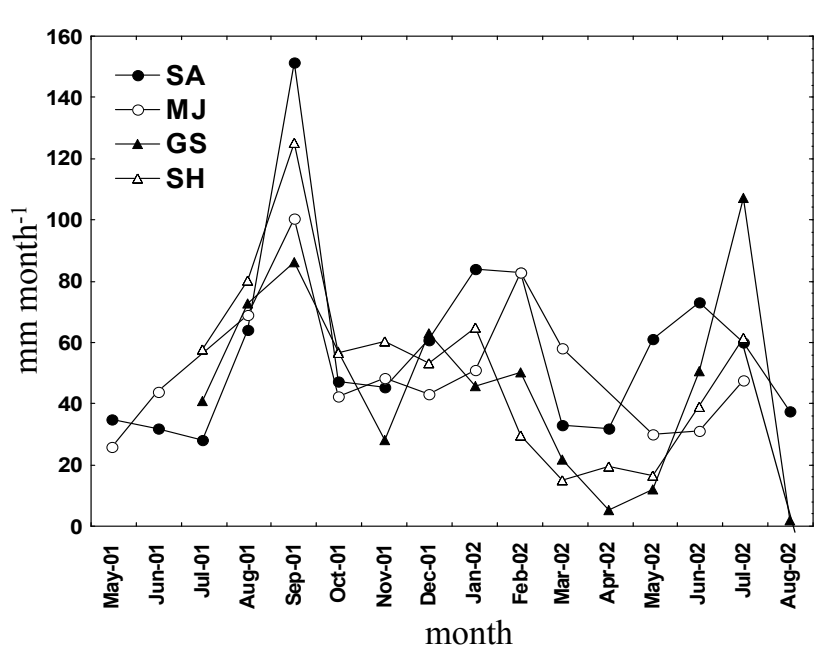

Fig. 2. Monthly precipitation at the investigated sites.

annual precipitation for the stations ranged from 533 to $763 \mathrm{~mm}$ (Table 1). The volume-weighted average concentrations (VWAC) were calculated for all available months for each station without interpolation (Table 2). The VWAC for ammonium ranged between 301 and $480 \mu \mathrm{g} \mathrm{N}^{-1}$ with the higher concentrations at the two southernmost stations (SA and MJ). The average of all four stations was $403 \mu \mathrm{g} \mathrm{N}^{-1}$. For nitrate the VWAC range was 353 to $561 \mu \mathrm{g} \mathrm{N}^{-1}$ and the average of stations was $436 \mu \mathrm{g} \mathrm{N}^{-1}$. Total nitrogen
VWAC ranged from 708 to $1027 \mu \mathrm{g} \mathrm{N}^{-1}$ with an average of $930 \mu \mathrm{g} \mathrm{N}^{-1}$. The VWAC of organic nitrogen was $11 \%$ or less of total nitrogen for all stations. Generally $\sim 10 \%$ of the VWAC of total nitrogen was organic and the remainder was approximately equal parts ammonium and nitrate (Table 2). The range of phosphate VWACs was 3.2 to $19.3 \mu \mathrm{g} \mathrm{Pl}^{-1}$ (Table 2) with substantially higher values at the southern stations (SA and MJ). No overall average was calculated because of the obvious differences between southern and northern stations. Differences between stations were smaller for organic $\mathrm{P}$ (range 1.5 to $4.4 \mu \mathrm{g} \mathrm{P}^{-1}$ ). The total phosphorus VWACs ranged from 5.1 to $23.7 \mu \mathrm{g} \mathrm{Pl}^{-1}$, reflecting the phosphate concentrations. Organic P constituted 12 to $39 \%$ of total phosphorus concentration with higher proportions at the isolated island stations (GS and SH). Pollman et al. (2002) found replicate precision to be poorest for concentrations exceeding $80 \mu \mathrm{gl}^{-1}$ and concluded that samples with such high concentrations of $\mathrm{P}$ were likely to be contaminated. The same criterion was adopted in this study, which excluded 3 analyses out of 56 .

\subsection{Nutrient loads}

The estimated annual total nitrogen load (Table 1) ranged from 387 (GS) to 727 (SA) $\mathrm{mg} \mathrm{N} \mathrm{m}^{-2} \mathrm{yr}^{-1}$ with the load at GS considerably smaller than the others. The proportions of nutrient species showed good agreement between VWACs (Table 2) calculated for the entire duration of the 

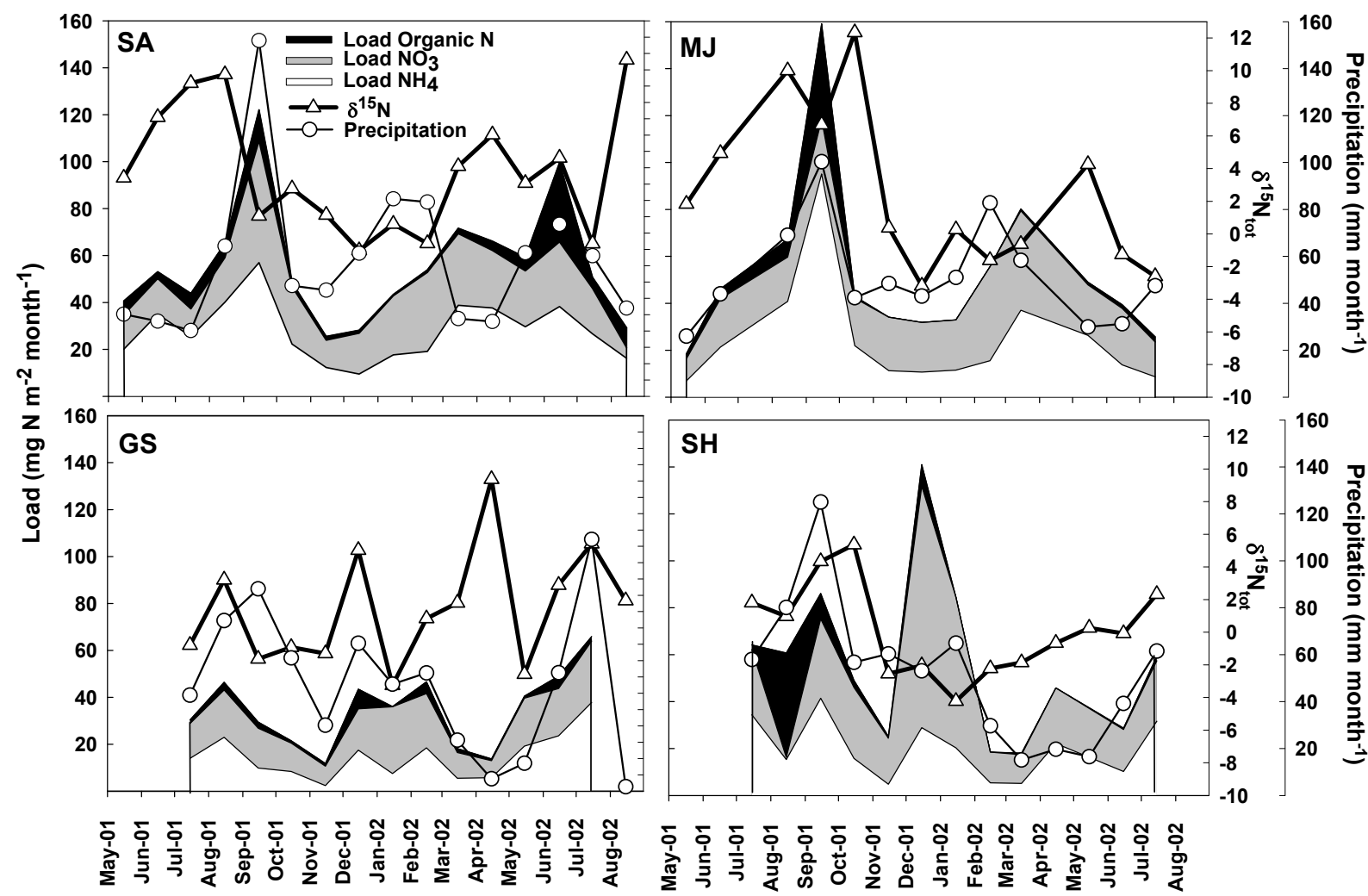

Fig. 3. Monthly precipitation, nitrogen loads and isotopic composition of total nitrogen at the investigated sites.

study at each station and the yearly loads calculated for July to June (Table 1), indicating that the rainy July and dry August of 2002 did not alter the overall result. The overall average load of total nitrogen for all stations was $617 \mathrm{mgN} \mathrm{m}^{-2} \mathrm{yr}^{-1}$. Recalculated deposition for the entire Baltic Proper $\left(\sim 213000 \mathrm{~km}^{2}\right.$ excluding the Gulfs of Finland and Riga) gives an annual load of 82-155 ktons of nitrogen per year (average $\sim 130$ ktons). Organic nitrogen constituted $\sim 10 \%$ of total deposition (Table 1). The proportion of nitrate deposited was higher at the two isolated islands (GS and $\mathrm{SH}, 52 \%$ and $56 \%$ ) than at the southern stations (SA and MJ, $41 \%$ and $43 \%$ ), mainly because the isolated islands had a winter peak of nitrate deposition (Fig. 3), which was absent at the two southern stations. The proportion of organic nitrogen was generally low, only in $10 \%$ of the cases did organic nitrogen exceed $15 \%$ of total nitrogen. High proportions of organic nitrogen appeared haphazardly (Fig. 3) and did not appear to be associated with season or high precipitation (Spearman rank order correlation coefficient $($ SROC $)=0.15$ ) or loads $(\mathrm{SROC}=0.14)$. Contamination can therefore not be excluded as an explanation.

Phosphorus deposition (Fig. 4, Table 1) was lower at the two isolated islands (GS and $\mathrm{SH}$ ) than at the two southern stations, close to large landmasses (SA and MJ). The total yearly $\mathrm{P}$ deposition for the two southern stations (SA and
MJ) was 15.8 and $7.4 \mathrm{mg} \mathrm{Pm}^{-2} \mathrm{yr}^{-1}$ respectively. For the isolated island stations (GS and $\mathrm{SH}$ ) the corresponding values were 2.8 and $3.3 \mathrm{mg} \mathrm{P} \mathrm{m}^{-2} \mathrm{yr}^{-1}$. Because of the clear differences between stations no overall average was calculated. The average proportion of organic phosphorus was almost twice as high at the isolated islands $(\sim 35 \%)$ as at the southern stations $(\sim 20 \%)$. All stations had greater deposition during spring and summer than during autumn and winter. N/P ratios for the total load were always considerably above Redfield ratio ( $\sim 7.2$ by weight). For the two southern stations, with higher phosphorus deposition, N/P ratios were 46 (SA) and $94(\mathrm{MJ})$. At the isolated islands (GS and $\mathrm{SH}$ ) the ratios were even higher, 136 and 200 respectively.

\subsection{Stable isotopic composition of nitrogen}

The seasonal range in $\delta^{15} \mathrm{~N}$ of total nitrogen $\left(\delta^{15} \mathrm{~N}_{\text {tot }}\right)$ was substantial, from $-4.2 \%$ o to $12.3 \%$ o (Fig. 3). The highest values were found in summer whereas winter values generally were low. The load-weighted annual averages of $\delta^{15} \mathrm{~N}$ (Table 1) were $\sim 3-4 \%$ o lighter at the isolated islands (GS and $\mathrm{SH}$ ) than at the southern stations (SA and MJ). High $\delta^{15} \mathrm{~N}$-values coincided with high proportions of ammonium (Fig. 3), with ammonium being $48 \%$ of the average annual nitrogen deposition at SA and MJ, but only $40 \%$ GS and $33 \%$ at SH (Table 1), mainly due to winter peaks of nitrate 

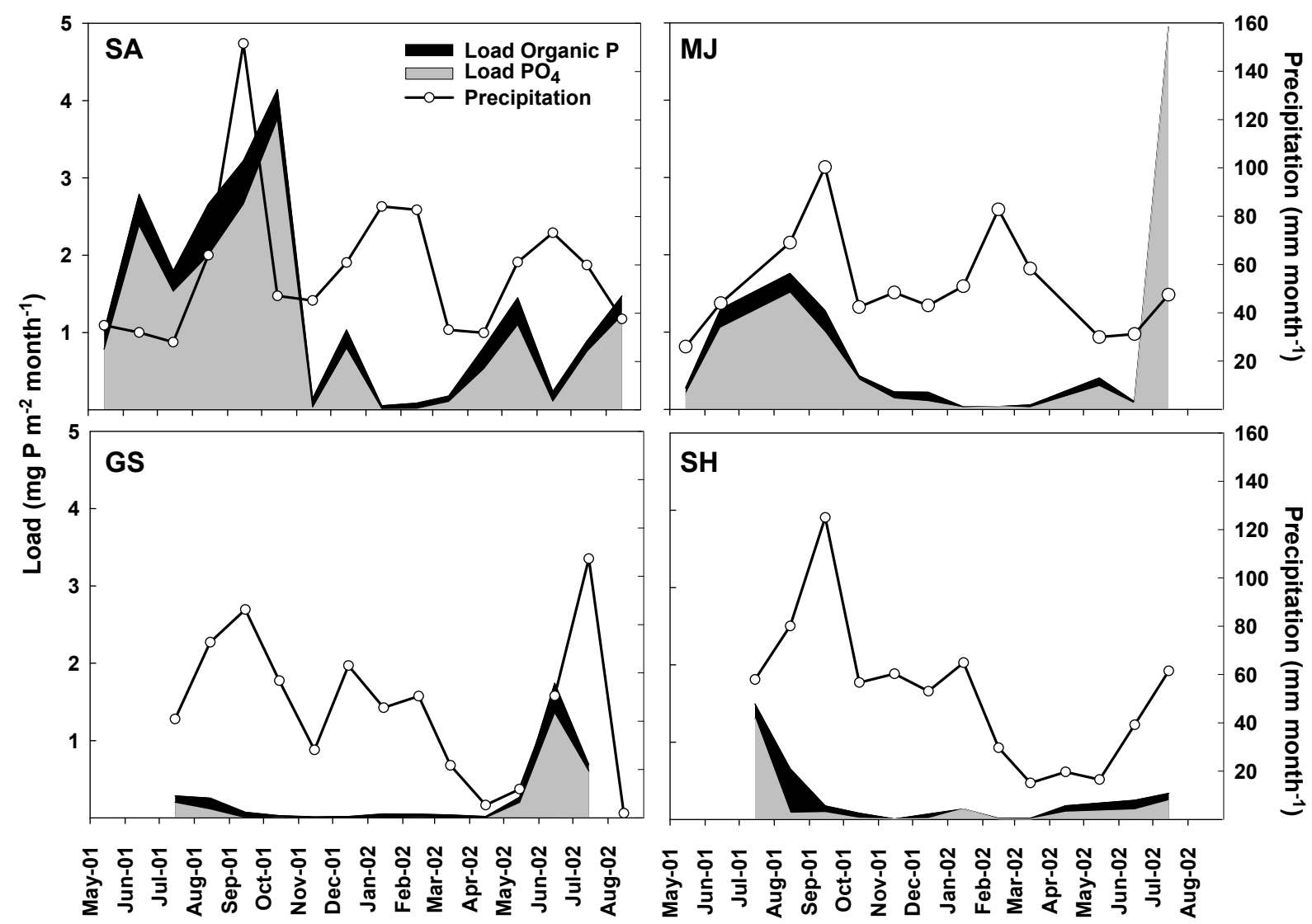

Fig. 4. Monthly precipitation and phosphorus loads at the investigated sites.

at the isolated islands (Fig. 3). The proportion of ammonium and nitrate in inorganic nitrogen showed a clear seasonal pattern at all stations (Fig. 5) with more ammonium in summer. Since combustion is the main source of atmospheric nitrate, it is reasonable to assume that its isotopic composition is lighter than ammonium, which is mainly derived from agricultural activities. Analyses of $\delta^{15} \mathrm{~N}$ were made on total nitrogen (see Methods) and the $\delta^{15} \mathrm{~N}$ of nitrate and ammonium were not determined separately. Therefore, our isotope based end-member calculations cannot consider the isotopic variability of the sources (see discussion, 4.3). The dependence between inorganic nitrogen species and $\delta^{15} \mathrm{~N}$ was therefore explored by a regression of the proportion of ammonium in the inorganic nitrogen fraction over $\delta^{15} \mathrm{~N}$. If the regression had used the proportion of ammonium in total nitrogen it would not allow extrapolation of the isotopic composition of end members $\left(100 \% \mathrm{NH}_{4}\right.$ or $\left.100 \% \mathrm{NO}_{3}\right)$. The percent of organic nitrogen was generally low (average $=7.1 \%, \mathrm{SD}=$ $7.2 \%$ ) and exceeded $15 \%$ in only five of 54 estimates. An extremely high estimate of $73 \%$ (station SH in August 2001) was excluded since contamination was feared.

A significant linear relation $\left(\delta^{15} \mathrm{~N}_{\text {tot }}=21.4 \cdot \mathrm{NH}_{4} \%-7.9\right.$, $R^{2}=0.58, P<0.001$ ) was found between percent ammonium in the inorganic part of nitrogen and $\delta^{15} \mathrm{~N}$ using all sam-

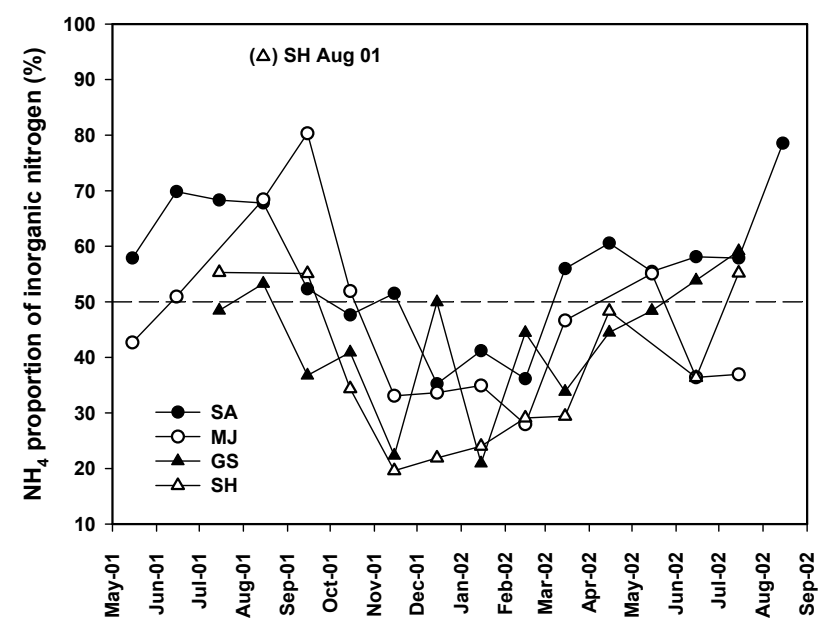

Fig. 5. Proportion of ammonium in dissolved inorganic nitrogen $\left(\mathrm{NH}_{4}+\mathrm{NH}_{3}\right)$ at the investigated sites.

ples (Fig. 6), and similar relations held for each station separately (regression lines indicated in Fig. 6) with GS showing the weakest linear dependence between proportion ammonium and $\delta^{15} \mathrm{~N}\left(R^{2}=0.78,0.58,0.30\right.$ and 0.48 for SA, 


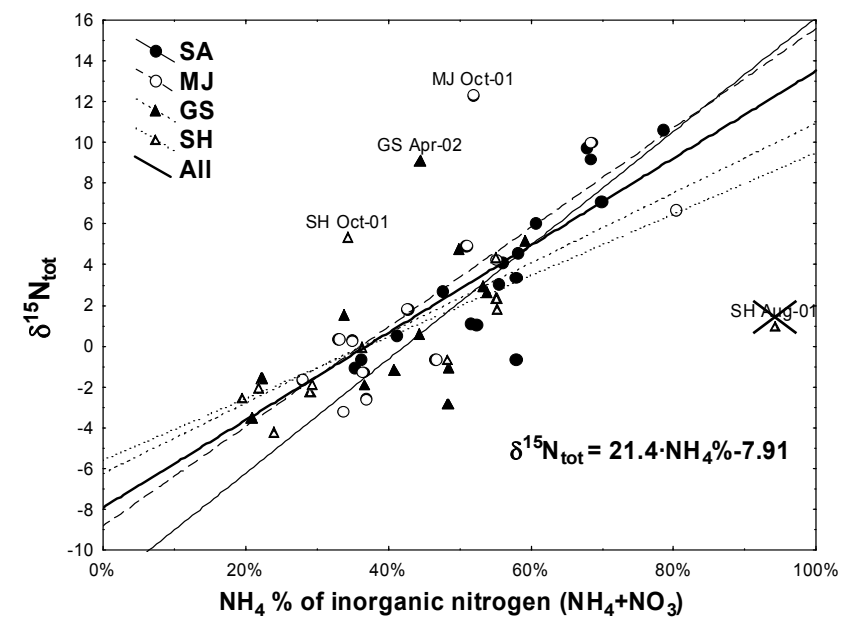

Fig. 6. Regression analysis of percent ammonium in the inorganic nitrogen on $\delta^{15} \mathrm{~N}_{\text {tot }}$. Regressions lines are indicated individually by stations and for a common regression of all stations.

MJ, GS and SH respectively, all with $P<0.05$ ). Calculation of end members from the common regression gives average $\delta^{15} \mathrm{~N}$ of approximately -7.9 (range -5.58 to -11.75 ) and 13.5 (range 9.5 to 16.2 )\%o in deposited nitrate or ammonium respectively. Treated separately the isolated islands suggest slightly smaller differences between the end members (Fig. 6). Three outliers were observed and indicated in Fig. 6. Organic nitrogen was $<6 \%$ for all of them and they were not in the outer tail of the distribution for any observed variable, except that precipitation and total nitrogen load was among the lowest observed at GS in April. Including them in the regression considerably decreased $R^{2}$, but there was no independent reason to exclude them, and excluding them had little effect on slope and intercept $\left(\delta^{15} \mathrm{~N}_{\text {tot }}=21.8 \cdot \mathrm{NH}_{4} \%-8.5\right.$, $\left.R^{2}=0.75, P<0.001\right)$.

The $\delta^{15} \mathrm{~N}_{\text {tot }}$ (Fig. 3) was not linearly correlated with precipitation $\left(R^{2}=0.01\right)$ or total nitrogen load $\left(R^{2}=0.18\right)$ and the seasonal differences are therefore most likely explained by the speciation of nitrogen. It is however of interest to determine the seasonal isotopic composition (Fig. 7) since isotopic budgeting of biological processes (e.g. food chain dynamics or nitrogen fixation) may be affected by the $\delta^{15} \mathrm{~N}$ of the atmospheric deposition. The un-weighted $\delta^{15} \mathrm{~N}_{\text {tot }}$ in deposition were investigated in two-way ANOVA with the factors "station" and "season", where winter was defined as October-March and summer as April-September (Table 3). There were no significant differences between stations but a clear difference between summer and winter season. Winter $\delta^{15} \mathrm{~N}_{\text {tot }}$ was consistently lower ( $\sim 2-4 \%$ o) than the corresponding summer values (Fig. 7) at all stations, as indicated by the lack of interaction effects in the ANOVA (Table 3 ). An overall average for summer $\delta^{15} \mathrm{~N}_{\text {tot }}$ was $3.2 \%$ and for winter $0.3 \%$. A decreasing trend in $\delta^{15} \mathrm{~N}$ from south to north was suggested by the station averages both in summer and

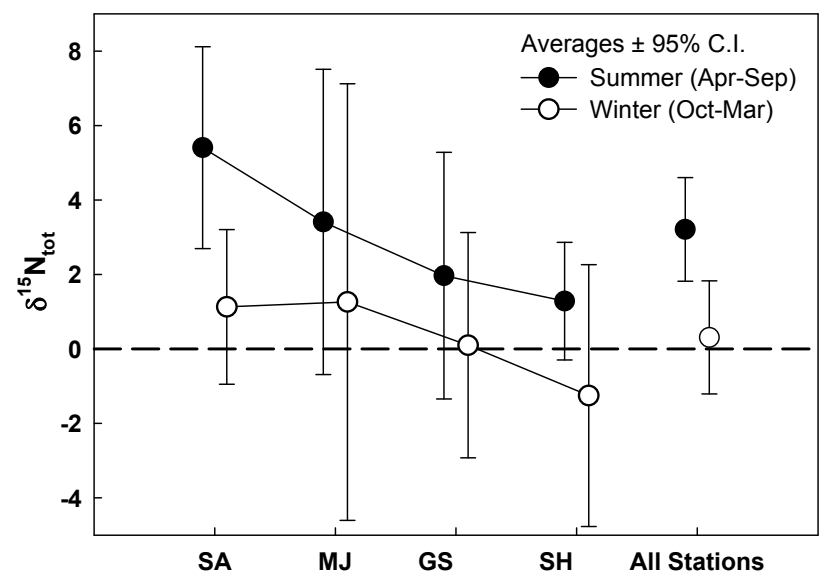

Fig. 7. Summer (April to September) and winter (October to March) seasonal averages of $\delta^{15} \mathrm{~N}_{\text {tot }}$ by stations and for all stations. The $95 \%$ confidence intervals indicated.

Table 3. ANOVA results for non-weighted $\delta^{15} \mathrm{~N}_{\text {tot }}$ analysed by stations and season. Summer: April to September, Winter: October to March.

\begin{tabular}{lcccccc}
\hline Effect & SS & Df & MS & F & P & \\
\hline Station & 84.8 & 3 & 28.3 & 2.1 & 0.113 & ns \\
Winter/Summer & 99.6 & 1 & 99.6 & 7.4 & 0.009 & $* *$ \\
Interaction & 12.7 & 3 & 4.2 & 0.3 & 0.815 & ns \\
Residual & 647.4 & 48 & 13.5 & & & \\
\hline
\end{tabular}

in winter but this result was not significant in the ANOVA. The power for the test of stations was however only $\sim 45 \%$, whereas it was $\sim 80 \%$ for seasons.

\section{Discussion}

4.1 Precipitation and volume weighted average nutrient concentrations

Global estimates of the atmospheric deposition are in the same range as the data from Baltic Sea from this study (Krom et al., 2004; Galloway, 1996) The estimated precipitation at the stations during the period July 2001 to June 2002 (Fig. 2), agrees well with a January to December annual precipitation of $\sim 500-800 \mathrm{~mm}$ in southern Sweden (from Fig. 3.15 covering the years 1860-1995 in Bergström et al., 2001). When compared with long-term June and July precipitation data from the national monitoring of precipitation, at the stations used in this study, the estimates were at all stations in the upper quartile of estimates for July to June (1961-2003), thereby potentially slightly overestimating annual loads. September 2001 was extremely rainy, with a very high precipitation estimate of $152 \mathrm{~mm}$ at the southernmost station (MJ). The concentrations of ammonium and 
nitrate agreed well with those generally found in the Swedish national monitoring (Kindbom et al., 2001). As in most other studies of atmospheric deposition for northern Europe and the US ammonium and nitrate constitute approximately equal parts of the inorganic nitrogen (Yeatman et al., 2001b, Russell et al., 1998). Organic nitrogen was generally below $10 \%$ and showed no obvious dependence on load, precipitation or season. Since the nitrogen concentrations found in this study agree well with the literature on nitrogen in precipitation for the region (e.g. Bartnicki et al., 2004), the discussion will be focussed on the isotopic signatures rather then on nitrogen concentrations and loads.

Measurements of phosphorus in precipitation at coastal stations are scarce and often only reported as phosphate. Some recent publications have however presented a substantial amount of data from North America and the eastern Mediterranean (Herut et al., 1999; Ahn and James, 2001; Pollman et al., 2002; Markaki et al., 2003; Koelliker et al., 2004; Krom et al., 2004; Carbo et al., 2005). For the New Jersey area the VWACs for total phosphorus were estimated to $4.1-15 \mu \mathrm{gPl}^{-1}$ (Koelliker et al., 2004) and in Florida Pollman et al. (2002) reported $5 \mu \mathrm{g} \mathrm{Pl}^{-1}$. Pollman et al. (2002) also reviewed recent literature estimates of rainfall concentrations ranging from 2 to $500 \mu \mathrm{g} \mathrm{Pl}^{-1}$ in a wide range of regions. For the eastern Mediterranean area VWACs of $4-18 \mu \mathrm{g}^{-1}$ phosphate $\mathrm{P}$ and $7-15 \mu \mathrm{gl}^{-1}$ total $\mathrm{P}$ are reported (Herut et al., 1999; Markaki et al., 2003). VWACs from Norwegian monitoring stations in 1998 ranged from 9 to $46 \mu \mathrm{gl}^{-1}$, with an average of $17 \mu \mathrm{gl}^{-1}$ (Solberg et al., 1999). The VWACs of total phosphorus found at the four sites in this study ranged from 5.1 to $23.7 \mu \mathrm{g} \mathrm{Pl}^{-1}$ (Table 2) and the organic proportion ranged from $12 \%$ to $39 \%$. Occurrence of high organic $\mathrm{P}$ proportions showed no seasonality (Fig. 4) but generally coincided with low concentrations and was more pronounced at the isolated islands (Tables 1 and 2). Since phosphorus in rain is generally derived from soil dust or incineration it was not unexpected to find 3-4 times higher VWACs at the southernmost stations (SA and MJ) than at the isolated islands, where the anthropogenic influence is smaller. There may also be a south-north gradient corresponding to the well-documented deposition gradient for nitrogen (Bartnicki et al., 2004), but in general the VWACs in this study were of the same magnitude as those found in the literature. There was no dependence between precipitation and concentration (data not presented) except at the southernmost station (SA) where high concentrations were associated with low precipitation.

\subsection{Nutrient loads}

Granat (2001) reviewed and synthesised the extensive literature on nitrogen deposition in the Baltic area. Using a long-range transport and deposition model he estimated wet and dry deposition of total nitrogen to be $800-1000 \mathrm{mgN} \mathrm{m}^{-2} \mathrm{yr}^{-1}$ in the Baltic Proper area, which is higher than the estimates found in this study $\left(\sim 600 \mathrm{mg} \mathrm{N} \mathrm{m}^{-2} \mathrm{yr}^{-1}\right)$. In a recent publication the average load was estimated to $684 \mathrm{~kg} \mathrm{~N} \mathrm{~km}^{-2}$ (Hertel et al., 2003) and the Helsinki Commission estimates it to $\sim 260 \mathrm{ktons} N$ for the year 2000 in the entire Baltic Sea area $\left(420000 \mathrm{~km}^{2}\right.$ ) (HELCOM, 2004). Applying the calculated average annual load of total N-deposition in this study $\left(617 \mathrm{~kg} \mathrm{~N} \mathrm{~km}^{-2}\right)$ to the same area gives an estimate of $\sim 259$ ktons. The agreement with other load studies however supports the assumption that the $\delta^{15} \mathrm{~N}_{\text {tot }}$ values found are representative for atmospheric nitrogen deposition on the Baltic Proper. The organic component of nitrogen in atmospheric deposition has been little studied, but in some areas it has been shown to constitute a substantial proportion of total deposition (Peierls and Paerl, 1997; Russell et al., 1998; Scudlark et al., 1998). The results in this study showed that for the Baltic Proper organic nitrogen was a small component, constituting on average $7-10 \%$ of total deposition. This agrees with Russell et al. (1998), who found that dissolved organic nitrogen (DON) constituted $\sim 13 \%$ of total dissolved nitrogen in wet deposition to the Chesapeake bay area. The collection method may, however, have contributed to the low DON contribution, since some DON may be adsorbed on the plastic bags and some may have been transformed to inorganic forms (Scudlark et al., 1998).

The most comparable recent estimates of atmospheric phosphorus deposition are those reported by Knulst (2001), who found annual deposition rates of 5.8, 23.0 and $116.2 \mathrm{~kg}$ total $\mathrm{P} \mathrm{km}^{-2} \mathrm{yr}^{-1}$ at three Swedish inland sites (Knulst, 2001). An average for a selection of Norwegian monitoring stations in 1998 was $181 \mathrm{~kg}$ total $\mathrm{P} \mathrm{km}^{-2} \mathrm{yr}^{-1}$ (Solberg et al., 1999). For the Israeli coast and the eastern Mediterranean Herut et al. (1999) report annual depositions of 5-16 kg dissolved inorganic phosphorous (DIP) $\mathrm{km}^{-2} \mathrm{yr}^{-1}$, while Krom et al. (2004) estimated $6.7 \mathrm{~kg}$ total $\mathrm{P} \mathrm{km}^{-2} \mathrm{yr}^{-1}$ and Markaki et al. (2003) report $3.7-5.2 \mathrm{~kg}$ total $\mathrm{P} \mathrm{km}^{-2} \mathrm{yr}^{-1}$ and $2 \mathrm{~kg} \mathrm{DIP} \mathrm{km}^{-2} \mathrm{yr}^{-1}$. They estimated that the DIP deposited during summer and autumn could account for up to $20-38 \%$ of marine new production during the same period. In the New Jersey area Koelliker et al. (2004) found the annual deposition at four stations to be $5.2-8.2 \mathrm{~kg}$ total $\mathrm{P} \mathrm{km}^{-2} \mathrm{yr}^{-1}$ and reported fluxes from eastern USA found in the literature ranging from 4 to $12 \mathrm{~kg}$ total $\mathrm{P} \mathrm{km}^{-2} \mathrm{yr}^{-1}$. In Florida wet deposition of $\mathrm{P}$ was estimated to $\sim 7.5 \mathrm{~kg}$ total $\mathrm{P} \mathrm{km}^{-2} \mathrm{yr}^{-1}$ by Pollman et al. (2002) and in their review they reported literature estimates of bulk depositions ranging from 4 to $230 \mathrm{~kg} \mathrm{~km}^{-2} \mathrm{yr}^{-1}$ in a wide range of environments. The results in this investigation, $2.8-15.8$ and 2$12.7 \mathrm{~kg} \mathrm{P} \mathrm{km}^{-2} \mathrm{yr}^{-1}$ for total $\mathrm{P}$ and $\mathrm{PO}_{4}-\mathrm{P}$, respectively, (Table 1) fall within the wide range found in the literature. The Helsinki Commission estimated the total load of phosphorus on the Baltic Sea in the year 2000 to be $\sim 34600$ ton (HELCOM, 2004), and assumed atmospheric deposition to be less than $5 \%$ of the total load. Applying the annual loads founds in this study to the same area $\left(420000 \mathrm{~km}^{2}\right)$ will yield 


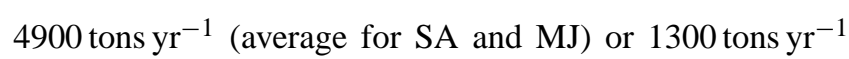
(average for GS and SH ) corresponding to $14 \%$ and $4 \%$ of the total load respectively. Assuming that the isolated islands are more representative for the open sea, the result therefore indicates that atmospheric deposition is a minor component of the phosphorus load on the open Baltic Proper.

Since most of the annual atmospheric phosphorus deposition appears to occur during the summer season, it may nevertheless influence the nitrogen-fixing cyanobacteria of the Baltic Proper. These form extensive surface accumulations in the Baltic Proper during the summer months July to August but there are few estimates of the specific production of the filamentous cyanobacteria. For Aphanizomenon Walsby et al.(1997) estimated the production to 4.2-13.2 $\mathrm{mmol} \mathrm{C} \mathrm{m}^{-2} \mathrm{~d}^{-1}$, while (Stal and Walsby, 2000) reported $5.8-10.5 \mathrm{mmol} \mathrm{C} \mathrm{m}^{-2} \mathrm{~d}^{-1}$. These estimates represent the bloom peak and cannot be generalised to the entire duration of the bloom. Larsson et al. (2001) presented production data for different size fractions of Baltic phytoplankton. The size fraction $>40 \mu \mathrm{m}$ was dominated by diazotrophic filamentous cyanobacteria (Larsson pers. com.) and can be used to derive an integrated filamentous cyanobacterial production of $\sim 2 \mathrm{~g} \mathrm{C} \mathrm{m}^{-2}$ for June to $\mathrm{Au}-$ gust, which is their main production season in the Baltic Proper. Calculating the June to August atmospheric deposition of phosphate for each station and year, replacing missing months with averages of those present the same year, and assuming that the cyanobacteria are able to function at C:P molar ratios of 420 the estimated maximal proportion of new cyanobacterial production potentially sustained by atmospheric deposition ranged from $\sim 4 \%$ (GS, 2001) to $\sim 60 \%$ (MJ, 2002). As an average for both years, the estimate was $\sim 38 \%$ and $\sim 12 \%$ for the southern stations and the isolated island stations, respectively. Since the latter are most likely to be representative for open sea conditions, it is not probable that the cyanobacterial blooms are primarily supported by atmospheric P deposition. Given the apparent episodic events of phosphorus deposition and the accumulation of cyanobacteria in surface water this source is however potentially important in initiating or prolonging a bloom event and thereby stimulating nitrogen fixation.

\subsection{Stable isotopic composition of nitrogen load}

The stable isotope composition of total nitrogen $\left(\delta^{15} \mathrm{~N}_{\text {tot }}\right)$ showed a clear covariance with season and the speciation of inorganic nitrogen (Figs. 3, 5 and 6). The result that DON constituted only a minor part of total nitrogen was used to extrapolate the potential isotopic composition of $\delta^{15} \mathrm{NO}_{3}$ and $\delta^{15} \mathrm{NH}_{4}$ using only the inorganic fraction. A necessary assumption in using this method is that $\delta^{15} \mathrm{~N}_{\mathrm{DON}}$ in the samples is not widely different from $\delta^{15} \mathrm{~N}$ of the inorganic nitrogen. There are few measurements of $\delta^{15} \mathrm{~N}_{\text {DON }}$ in rain but Cornell et al. (1995) found a linear relation between $\delta^{15} \mathrm{~N}_{\mathrm{DON}}$ and nitrate concentration, whereas Russell et al. (1998) found that the sources of DON in rain were unrelated to both $\delta^{15} \mathrm{NO}_{3}$ and $\delta^{15} \mathrm{NH}_{4}$. In general Russell et al.(1998) found that $\delta^{15} \mathrm{~N}_{\text {DON }}$ ranged between -0.5 and $14.7 \%$ with a median of $\sim 5.0 \%$ o whereas Cornell et al. (1995) presented $\delta^{15} \mathrm{~N}_{\text {DON }}$ values between -7 and $7 \%$ from various locations. The low proportions of DON and the relatively small isotopic difference between DON and inorganic nitrogen found in the literature, supports the use of regression extrapolation to estimate $\delta^{15} \mathrm{NO}_{3}$ and $\delta^{15} \mathrm{NH}_{4}$ (Fig. 6). The large differences between $\delta^{15} \mathrm{NO}_{3}$ and $\delta^{15} \mathrm{NH}_{4}$ extrapolated in this study are in contrast to those directly measured by Russell et al. (1998) where both $\delta^{15} \mathrm{NO}_{3}$ and $\delta^{15} \mathrm{NH}_{4}$ were generally similar and with medians close to zero $(-0.5$ and $-1.1 \%$ respectively). In that study, the range of $\delta^{15} \mathrm{NH}_{4}$ estimates (-8.3 to 8.6\%o) was considerably wider than the range of approximately $(-4.0$ to $4.4 \%$ o) for $\delta^{15} \mathrm{NO}_{3}$. In the same paper literature data for $\delta^{15} \mathrm{~N}$ in rain are reviewed and the ranges found were -15 to $10 \%$ o for $\delta^{15} \mathrm{NH}_{4}$ and -16 to $7 \%$ o for $\delta^{15} \mathrm{NO}_{3}$ (estimated from the Figs. 1 and 2 in Russell et al., 1998). In Florida rain, Dillon and Chanton (2005) found $\delta^{15} \mathrm{~N}$ values of ammonia of -11.6 to $-0.3 \%$ and of nitrate -5.1 to $3.8 \%$ o, similar to the tendency found in this study. Yeatman et al. (2001b) found that the range of aerosol $\delta^{15} \mathrm{NH}_{4}$ was -20 to $20 \%$ o (heavier near rural areas, lighter near urban areas) and the range for $\delta^{15} \mathrm{NO}_{3}$ was -6 to $9 \%$.

The load weighted average (LWA) $\delta^{15} \mathrm{~N}_{\text {tot }}$ of the nitrogen deposited on the Baltic can be used to constrain basinwide nitrogen budget calculations and to identify qualitative changes in the sources. The LWA $\delta^{15} \mathrm{~N}_{\text {tot }}$ (Table 1) was considerably lighter at stations GS and SH $(0-0.7 \%$ o ) than at stations SA and MJ (3.6-3.8\%o). High winter nitrate concentration corresponded to low $\delta^{15} \mathrm{~N}_{\text {tot }}$ and high summer ammonium concentrations to high $\delta^{15} \mathrm{~N}_{\text {tot }}$. On the isolated islands more than $50 \%$ of nitrogen was deposited as nitrate, whereas only $\sim 40 \%$ was nitrate at the southern stations (Table 1 ). The isolated islands, especially station $\mathrm{SH}$, had nitrate-dominated winter peaks of nitrogen deposition, which were absent at the other stations. These nitrate peaks could be caused by emissions of combustion $\mathrm{NO}_{\mathrm{x}}$ from ships, since major Baltic ship routes pass close to the islands (HELCOM, 2007). The proximity of stations SA and MJ to agricultural areas probably caused the higher proportion of ammonium in the load estimates. High ammonium and low $\delta^{15} \mathrm{~N}$ are suggested to indicate emissions from fields and live-stock husbandry (Russell et al., 1998). The higher proportions of nitrate in the rain at GS and SH is the most likely cause of the lighter $\delta^{15} \mathrm{~N}_{\text {tot }}$ at these stations, which are likely to best represent the open sea. Atmospherically deposited nitrogen in the Baltic is therefore isotopically light $(\sim 0 \%)$, similar to the gaseous nitrogen fixed by cyanobacteria. Höglander (2005) found the summer $\delta^{15} \mathrm{~N}$ in filamentous nitrogen fixing cyanobacteria in the open sea to be $-1.53 \pm 0.49$ (average \pm SD). Basin wide budgeting of nitrogen could therefore overestimate nitrogen fixation if the atmospheric nitrogen LWA $\delta^{15} \mathrm{~N}_{\text {tot }}$ is not considered, and the same is true for sediment cores, where light $\delta^{15} \mathrm{~N}$ could 
be interpreted as a result of nitrogen fixation only. Direct budget calculations of nitrogen fixation from changes in the isotopic composition of seston during cyanobacterial blooms would on the other hand underestimate fixation, if the relatively heavy ammonium deposited during the summer is not taken into account (Fig. 7).

\section{Conclusions}

This study shows that the load-weighted annual atmospheric nitrogen deposition on the Baltic Proper is isotopically light $\left(\delta^{15} \mathrm{~N} \sim 0 \%\right)$ and therefore similar to nitrogen fixed by cyanobacteria. In large-scale isotope-based nitrogen budgets, atmospherically deposited nitrogen could therefore be interpreted as nitrogen fixed by cyanobacteria, potentially leading to overestimates of nitrogen fixation. While the atmospheric phosphorus load is not likely to be the major source of phosphorus for summer cyanobacterial blooms in the open Baltic Proper, $\mathrm{P}$ deposition in precipitation could potentially prolong an existing bloom. By end member extrapolation from regression the long-term average isotopic composition of nitrate and ammonium were found to be approximately $-7.9 \%$ o and $13.5 \%$ respectively, indicating combustion as the source of nitrate and agricultural activities as sources of ammonium. The differences are sufficiently large to be used in budgeting and detection of changes in the source composition of load. The isotopic composition of atmospherically deposited nitrogen was heavier in summer than in winter at all stations, reflecting a higher proportion of ammonium in summer.

Acknowledgements. This work was supported by the European Commission's Environment and Sustainable Development Programme (Signal Project, EVK3-CT-1999-00020) and the Swedish MISTRA project MARE. We thank the laboratory of the Department of Systems Ecology at the Stockholm University for nutrient analyses and Lisa Adelsköld for excellent technical help.

Edited by: S. Bouillon

\section{References}

Ahn, H.: Estimating the mean and variance of censored phosphorus concentrations in Florida rainfall, J. Am. Water Resour. As., 34, 583-593, 1998.

Ahn, H. and James, R. T.: Outlier detection in phosphorus dry deposition rates measured in South Florida, Atmos. Environ., 33, 5123-5131, 1999.

Ahn, H. and James, R. T.: Variability, uncertainty, and sensitivity of phosphorus deposition load estimates in South Florida, Water Air Soil Poll., 126, 37-51, 2001.

Bartnicki, J., Gusev, A., Berg, T., and Fagerli, H.: Atmospheric supply of nitrogen, lead, cadmium, mercury and lindane to the Baltic Sea in 2002, EMEP Centres Joint Report for HELCOM, EMEP/MSC-W Technical report 3/2004, 2004.

Bergström, S., Alexandersson, H., Carlsson, B., Josefsson, W., Karlsson, K.-G., and Westring, G.: Climate and hydrology of the Baltic basin, in: A systems analysis of the Baltic Sea, edited by: Wulff, F. V., Rahm, L. A., and Larsson, P., Springer-Verlag, New York, Berlin, 75-110, 2001.

Carbo, P., Krom, M. D., Homoky, W. B., Herut, B.: Impact of atmospheric deposition on $\mathrm{N}$ and $\mathrm{P}$ geochemistry in the southeastern Levantine basin, Deep Sea Research II, 52, 22-23, 3041-3053, 2005.

Cornell, S., Rendell, A., and Jickells, T.: Atmospheric inputs of dissolved organic nitrogen to the oceans, Nature, 376, 243-246, 1995.

Duce, R. A., Roche, J. L., Altieri, K., Arrigo, K., Baker, A., Capone, D., Cornell, S., Dentener, F., Galloway, J., Ganeshram, R., R.Geider, Jickells, T., Kuypers, M., Langlois, R., Liss, P. S., Liu, S. M.,Middelburg, J., Moore, C. M., Nickovic, S., Oschlies, A., Pedersen, T., Prospero, J., Seitzinger, S., Sorensen, L. L., Uematsu, M., Ulloa, O., Voss, M., Ward, B., and Zamora, L.: Impacts of Atmospheric Anthropogenic Nitrogen on the Open Ocean, Science, 3205878 , doi:10.1126/science.1150369, 893897, 2008.

Elmgren, R.: Understanding Human Impact on the Baltic Ecosystem: Changing Views in Recent Decades, Ambio, 30, 4-5, 222231, 2001.

Galloway, J. N., Dentener, F. J., Capone, D. G., Boyer, E. W., Howarth, R. W., Seitzinger, S. P., Asner, G. P., Cleveland, C. C., Green, P. A., Holland, E. A., Karl, D. M., Michaels, A. F., Porter, J. H., Townsend, A. R., and Vörösmarty, C. J.: Nitrogen cycles: past, present, and future, Biogeochemistry, 70, 153-226, 2004.

Galloway, J. N., Howarth, R. W., Michaels, A. F., Nixon, S. W., Prospero, J. M., and Dentener, F. J.: Nitrogen and phosphorus budgets of the North Atlantic Ocean and its watershed, Biogeochemistry, 35, 3-25, 1996.

Granat, L.: Deposition of nitrate and ammonium from the atmosphere to the Baltic Sea, in: A Systems Analysis of the Baltic Sea, edited by: Wulff, F. V., Rahm, L. A., and Larsson, P., Springer-Verlag, Berlin Heidelberg, 133-148, 2001.

Gruber, N. and Galloway, J. N.: An Earth-system perspective of the global nitrogen cycle, Nature, 451, 293-296, 2008.

HELCOM: Baltic Sea Environment Proceedings: The Fourth Baltic Sea Pollution Load Compilation Baltic Marine Environment Protection Commission, Helsinki, 2004.

HELCOM: Towards a Baltic Sea with environmentally friendly maritime activities, Background document for the HELCOM Ministerial Meeting 2007, HELCOM Secretariat, http://www.helcom.fi/stc/files/Krakow2007/ Maritime_activities_MM2007.pdf, 2007.

Hertel, O., Skjoth, C. A., Brandt, J., Christensen, J. H., Frohn, L. M., and Frydendall, J.: Operational mapping of atmospheric nitrogen deposition to the Baltic Sea, Atmos. Chem. Phys., 3, 2083-2099, 2003, http://www.atmos-chem-phys.net/3/2083/2003/.

Herut, B., Krom, M. D., Pan, G., and Mortimer, R.: Atmospheric input of nitrogen and phosphorus to the Southeast Mediterranean: Sources, fluxes, and possible impact, Limnol. Oceanogr. 44, 1683-1692, 1999.

Höglander, H.: Studies of Baltic Sea plankton - spatial and temporal patterns, University of Stockholm, 133 pp., 2005.

Kindbom, K., Svensson, A., Sjöberg, K., and Persson, C.: Nationell miljöövervakning av luft- och nederbördskemi 1997, 1998 och 
1999, IVL Rapport/report 1420, 2001.

Knulst, J. C.: Phosphorus in precipitation. Results from measurements during the 1990's, IVL Rapport/report B 1442, 2001.

Koelliker, Y., Totten, L. A., Gigliotti, C. L., Offenberg, J. H., Reinfelder, J. R., Zhuang, Y., and Eisenreich, S. J.: Atmospheric wet deposition of total phosphorus in New Jersey, Water Air Soil Poll., 154, 139-150, 2004.

Koroleff, F.: Determination of nutrients, in: Methods of Seawater Analysis, edited by: Grasshoff, K., Erhardt, M., and Kremling, K., Verlag Chemie, 125-139 phosphorous, 162-173 nitrogen, 1983.

Krom, M. D., Herut, B., and Mantoura, R. F. C.: Nutrient budget for the Eastern Mediterranean: implications for phosphorus limitation, Limnol. Oceanogr., 49, 5, 1582-1592, 2004.

Kullenberg, G.: Physical oceanography, in: The Baltic Sea, edited by: Voipio, A., Elsevier Publishing Company, Amsterdam, 135$182,1981$.

Larsson, U., Hadju, S., Walve, J., and Elmgren, R.: Baltic Sea nitrogen fixation estimated from the summer increase in upper mixed layer total nitrogen, Limnol. Oceanogr., 46, 4, 811-820, 2001.

Markaki, Z., Oikonomou, K., Kocak, M., Kouvarakis, G., Chaniotaki, A., Kubilay, N., and Mihalopoulos, N.: Atmospheric deposition of inorganic phosphorus in the Levantine Basin, eastern Mediterranean: Spatial and temporal variability and its role in seawater productivity, Limnol. Oceanogr., 48, 1557-1568, 2003.

Morales, J. A., Sanchez, L., Velasquez, H., Borrego, B. D., Nava, M. D., Portillo, D., Cano, Y. L., Morillo, A., Albornoz, A., and Socorro, E.: Nutrient loading by precipitation in the Maracaibo Lake basin, Venezuela, Water Air Soil Poll., 130, 511-516, 2001.

Paerl, H. W.: Coastal eutrophication in relation to atmospheric nitrogen deposition - Current perspectives, Ophelia, 41, 237-259, 1995.

Paerl, H. W.: Coastal eutrophication and harmful algal blooms: Importance of atmospheric deposition and groundwater as "new" nitrogen and other nutrient sources, Limnol. Oceanogr., 42, 1154-1165, 1997.
Peierls, B. L. and Paerl, H. W.: Bioavailability of atmospheric organic nitrogen deposition to coastal phytoplankton, Limnol. Oceanogr., 42, 1819-1823, 1997.

Pollman, C. D., Landing, W. M., Perry, J. J., and Fitzpatrick, T.: Wet deposition of phosphorus in Florida, Atmos. Environ., 36, 2309-2318, 2002.

Rolff, C. and Elmgren, R.: Use of riverine organic matter in plankton food webs of the Baltic Sea, Mar. Ecol. Progr. Ser., 197, 81$101,2000$.

Russell, C. M., Galloway, J. N., Macko, S. A., Moody, J. L., and Scudlark, J. R.: Sources of nitrogen in wet depositions to the Chesapeake Bay region, Atmos. Environ., 32, 2453-2465, 1998.

Scudlark, J. R., Russell, K. M., Galloway, J. N., Church, T. M., and Keene, W. C.: Organic nitrogen in precipitation at the midAtlantic US coast - Methods evaluation and preliminary measurements, Atmos. Environ., 32, 1719-1728, 1998.

Solberg, S., Breivik, K., Clarke, N., Groeggen, T., Roesberg, I., Toerseth, K., Aamlid, D., and Aas, W.: Intensiva skogovervåkningsflater. resultater fra 1998, Aktuelt fra SkogForsk 5/99, NISK, 24 pp., 1999.

Stal, L. J. and Walsby, A. E.: Photosynthesis and nitrogen fixation in a cyanobacterial bloom in the Baltic Sea, Eur. J. Phycol., 35, 97-108, 2000.

Walsby, A. E., Haye, P. K., Boje, R., and Stal, L. J.: The selective advantage of buoyancy provided by gas vesicles for planktonic cyanobacteria in the Baltic Sea, New Phytol., 136, 407417, 1997.

Yeatman, S. G., Spokes, L. J., Dennis, P. F., and Jickells, T. D.: Can the study of nitrogen isotopic composition in size-segregated aerosol nitrate and ammonium be used to investigate atmospheric processing mechanisms?, Atmos. Environ., 35, 1337 1345, 2001a.

Yeatman, S. G., Spokes, L. J., Dennis, P. F., and Jickells, T. D. Comparisons of aerosol nitrogen isotopic composition at two polluted coastal sites, Atmos. Environ., 35, 1321-1335, $2001 \mathrm{~b}$. 